\title{
Cultivating the Next Generation of Forensic Scientists Through Science, Technology, Engineering, and Mathematics (STEM)
}

\author{
Dutton GJ ${ }^{1}$, LaPorte $\mathbf{G M}^{1}$, Wagstaff $\mathbf{I R}^{2}$ and Spivak HR ${ }^{1}$ \\ ${ }^{1}$ United States Department of Justice, National Institute of Justice, Washington, DC, USA \\ ${ }^{2}$ American Academy for Advancement in Science, Washington, DC, USA
}

*Corresponding author: Dutton GJ, National Institute of Justice, Washington, DC, USA; Tel: 2025320118; E-mail: gregory.dutton@usdoj.gov

Received date: April 7, 2017; Accepted date: July 7, 2017; Published date: July 9, 2017

Copyright: (c) 2017 Dutton GJ, et al. This is an open-access article distributed under the terms of the Creative Commons Attribution License, which permits unrestricted use, distribution, and reproduction in any medium, provided the original author and source are credited.

\section{Commentary}

The National Institute of Justice (NIJ), the research and evaluation arm of the US Department of Justice, is the federal government's lead agency for forensic science research, development and evaluation, as well as for the administration of programs dedicated to assisting our nations forensic laboratories to increase efficiency and ultimately reduce their backlogs of evidence awaiting scientific analysis. The need for this assistance has never been greater because our forensic science laboratories continue to be overwhelmed with unprecedented demands for DNA and other forensic analysis while keeping up with the latest advances. The Bureau of Justice Statistics (BJS) estimated that publicly funded crime labs received an estimated 3.8 million forensic requests in 2014 and completed 3.6 million requests that year [1]. BJS also reported that at the end of 2014, U.S. crime labs had an estimated backlog of 570,100 requests for forensic services with $38 \%$ of these labs outsourcing one or more types of services. Because each 'forensic request' can involve multiple items and multiple tests per item, the number of individual tests is staggering; delays in processing evidence ultimately delays the administration of justice.

As is true for any scientific field, in the forensic sciences there is a need to continually strengthen the scientific underpinnings and seek new innovations. Indeed, one obvious approach to address this challenge is to support rigorous research, development and innovation by engaging researchers from various scientific backgrounds. In 2009, the National Academies of Sciences (NAS) released the report, Strengthening Forensic Science in the United States: A Path Forward [2]. One of the recommendations in the 2009 NAS was "to attract students in the physical and life sciences to pursue graduate studies in multidisciplinary fields critical to forensic science... to improve and develop graduate education programs... To make these programs appealing to potential students, they must include attractive scholarship and fellowship offerings. Emphasis should be placed on... funding research programs to attract research universities and students in fields relevant to forensic science."

Because forensic science is the application of science to address matters of law, forensic science is composed of a broad array of academic disciplines that include degrees in the basic sciences, technology, engineering, and mathematics (STEM) fields. Gonzalez and Kuenzi [3] further describe STEM as a collective term that embodies the interrelatedness of the four disciplines as it relates to education. Most forensic scientists typically obtain a baccalaureate, masters, or postdoctoral degree in chemistry or biology and then specialize in a specific area of study such as toxicology, pathology, or DNA [4]. This broad spectrum of scientific disciplines then gives rise to many forensic sub-disciplines that require specialized training and expertise. Figure 1 shows the most common forensic disciplines and their relationship to the applied and life sciences. Due to the inherent nature of the forensic sciences, and the broad scope and depth of disciplines needed to address a variety of crime related problems, research and development in all areas of science and engineering need to be employed.

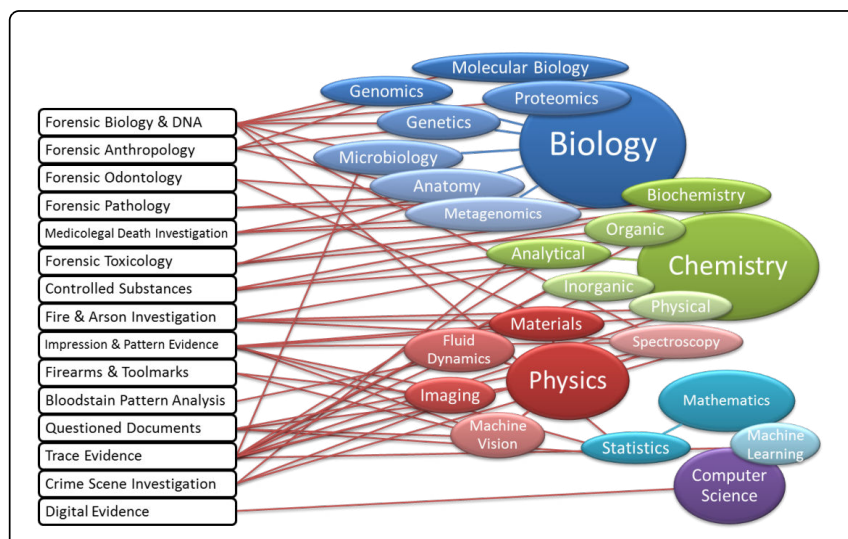

Figure 1: The most common forensic disciplines and their relationship to the applied and life sciences.

Carnevale et al. [5] projected that the number of STEM jobs would grow by 17 percent between 2008 and 2018, making it one of the most dynamic occupation clusters in the economy, a fact which may have particular consequence for a criminal justice system increasingly reliant upon computer and digital forensic applications. The importance of STEM and its vital relation to U.S. global competitiveness, national security, and scientific literacy, was documented in another groundbreaking 2007 NAS report, Rising Above the Gathering Storm: Energizing and Employing America for a Brighter Economic Future [6]. The committee expressed their concern that "a]lthough many people assume that the United States will always be a world leader in science and technology, this may not continue to be the case inasmuch as great minds and ideas exist throughout the world. We fear the abruptness with which a lead in science and technology can be lost-and the difficulty of recovering a lead once lost, if indeed it can be regained at all."

Recognizing how vital science and technology is to our future, a key component of NIJ's long term strategic approach to strengthen the underpinnings of the forensic sciences is to cultivate the next generation of STEM scientists and introduce the broader scientific fields to the challenges and needs of the forensic science community. The vision of forensic science at NIJ - Justice through sound science, scientists, and forensic practice - helps guide this long-term strategy 
Citation: Dutton GJ, LaPorte GM, Wagstaff IR, Spivak HR (2017) Cultivating the Next Generation of Forensic Scientists Through Science, Technology, Engineering, and Mathematics (STEM). J Forensic Res 8: 384. doi:10.4172/2157-7145.1000384

Page 2 of 3

and mission to advance forensic science through research, resources, and innovation that will ultimately protect the public and ensure justice for all. And, integral to this strategy is the creation of NIJ's Graduate Research Fellowship (GRF) program in STEM or GRFSTEM, which is the focus of this discussion. The STEM academic pathway is central to NIJ's ability to effectively serve its ultimate stakeholders, the nearly 500 forensic laboratories and the criminal justice professionals that rely on forensic evidence.

\section{NIJ GRF-STEM Program}

In the spring of 2014, NIJ's Office of Science and Technology (OST) and Office of Investigative and Forensic Sciences (OIFS) jointly introduced the GRF-STEM program. The goal of the GRF-STEM program is to increase the pool of researchers in science, technology, engineering, or mathematics that will provide solutions to better ensure public safety, prevent and control crime, and ensure the fair and impartial administration of criminal justice in the United States. The GRF-STEM track is open to doctoral students in the following fields of study:
1. Anthropology (physical)
2. Biology
3. Chemistry
4. Cognitive Science
5. Geoscience
6. Geographical Information Systems
7. Information Sciences
8. Materials Science
9. Mathematical Sciences
10. Pathology
11. Physics

\section{Engineering}

In its first application cycle, with very little in the way of outreach to the academic community, the GRF-STEM program received five applications from five schools and made three awards. In the fall of 2014, OST and OIFS strategically introduced several key revisions to the GRF-STEM program to make it more appealing and potentially competitive to some of the nation's top young scientists, including the following:

1. The annual stipend level was increased from $\$ 30,000$ to $\$ 35,000$;

2. In addition to the $\$ 35,000$ stipend, a competitive funding track for up to $\$ 15,000$ was established to cover research, tuition and mandatory fees, professional activities, and related expenses, at the discretion of the applicant;

3. The number of possible funding years was extended from one to three;

4. The application period was increased to over 100 days; and

5. A "Dear Colleague Letter" was extensively distributed to universities and numerous professional organizations across the country.
As a result, as shown in Figure 2, the number of applications has continued to steadily increase from 33 in 2015 to 53 in 2017. In any grant making program, a steady increase in applications is not just a strong indicator of the need for such grants, but the growth in demand also suggests that the strategic effort to create a competitive pool has been highly successful.

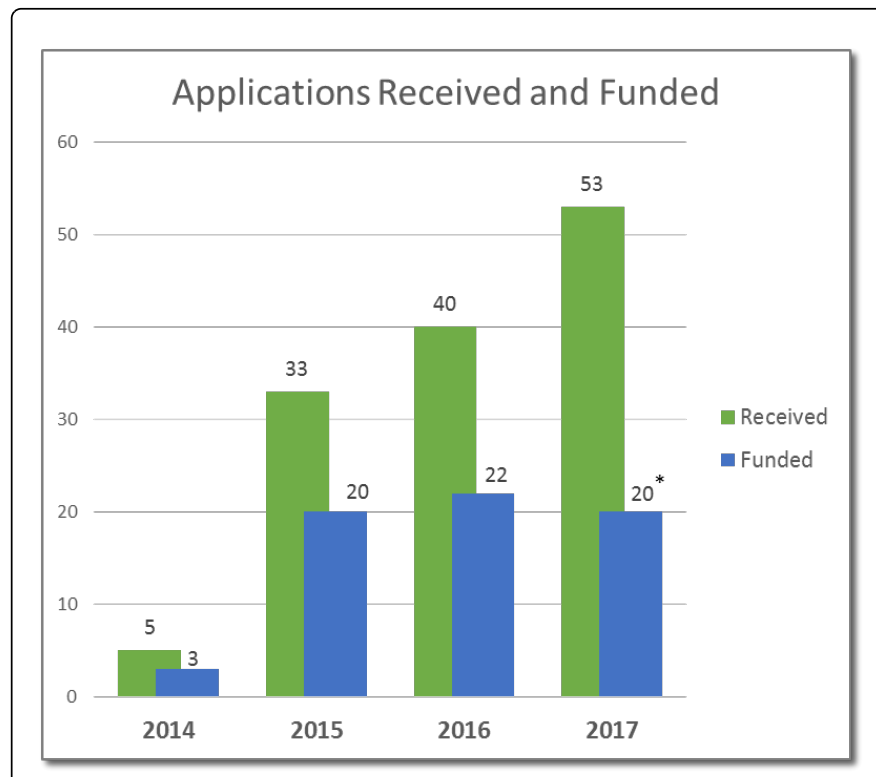

Figure 2: The number of applications received and awards made through NIJ's GRF-STEM program for Fiscal Year 2014 through 2017.

Central to NIJ's efforts to build a STEM program in the forensic sciences, which include a broad scope and depth of disciplines, is a commitment to increase diversity to broaden the field of researchers in all possible ways such as gender, race, ethnicity, experience, knowledge, and background. NIJ has developed and implemented an aggressive outreach and dissemination effort to include collaborating with professional scientific organizations with diverse membership profiles. NIJ recently partnered with the White House Initiative on HBCUs (WHIHBCU) to facilitate two webinars to share opportunities for graduate student and faculty researchers. As a result of this strategic collaboration, NIJ was invited to serve on a panel titled Education and Justice at the $2016 \mathrm{HBCU}$ Week Conference to discuss opportunities in forensic science and criminal justice with undergraduate/graduate students and faculty from around the country.

Figure 3 illustrates the diversity of scientists that have applied to NIJ's GRF-STEM program with applicants in numerous scientific disciplines from various geographic locations throughout the United States. The applicant pool is evenly divided with respect to males and females, with $80 \%$ of the applicants from public academic institutions and $20 \%$ from private academic institutions. Most federal agencies with substantial investments in science and engineering research and development have implemented aggressive strategies to support STEM. While these programs are undeniably important for supporting the nation's overall STEM academic pathway, they are all the more crucial for applied research agencies (particularly one like NIJ which must attract STEM scientists into applying their knowledge to the criminal justice system). By creating competitive opportunities for STEM scholars to engage directly with the mission-critical work of federal 
Citation: Dutton GJ, LaPorte GM, Wagstaff IR, Spivak HR (2017) Cultivating the Next Generation of Forensic Scientists Through Science, Technology, Engineering, and Mathematics (STEM). J Forensic Res 8: 384. doi:10.4172/2157-7145.1000384

Page 3 of 3

agencies, the agencies are in effect expanding their own pool of future researchers with the interest, experience, skillset, and awareness of such crucially important applied research programs. Arguably, nowhere is such foresight and cultivation more important than at small federal agencies-such as the National Institute of Justice-with highly targeted missions and niche research programs (Figure 3).

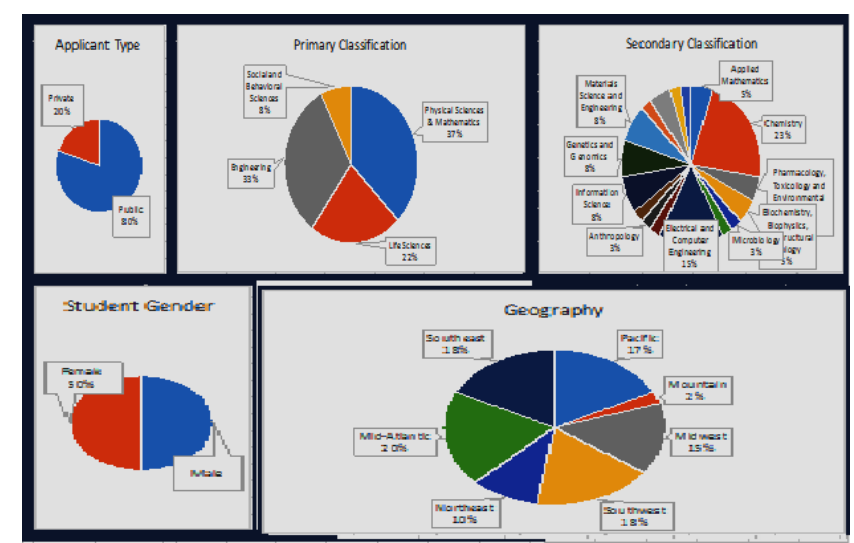

Figure 3: Applicant profiles based on gender, geography, and primary scientific discipline.

In 2015, the NAS released the NIJ-commissioned report Support for Forensic Science Research: Improving the Scientific Role of the National Institute of Justice. [7]. The NAS noted that "NIJ has a unique and critical role" among the diverse federal agencies working to impact the progress of forensic science because NIJ focuses on forensic science research and development, unlike the other agencies. The NAS also concluded that NIJ should continue on its current path and provide a plan for building on its progress by taking strategic steps to support high-quality forensic science research. The NAS also found that the efforts of NIJ have: "... contributed to the building of a research infrastructure necessary to develop and sustain research that advances forensic science methods." With this affirmation from the NAS and the well substantiated needs and benefits of STEM programs, NIJ remains steadfast in its commitment to developing and sustaining a premiere STEM program to help address real life criminal justice issues in the forensic sciences.

\section{Moving Forward}

NIJ recognizes that the forensic science community has immediate needs that arise primarily from the state and local forensic laboratories that face the dual challenges of satisfying increasing demand for forensic testing while keeping up with the latest technological advances. But, there is also a long-term need for innovative technologies, which will be fueled by the next generation of scientists. Therefore, NIJ is committed to engaging and supporting the best and brightest talent - through the GRF-STEM program - to assist with advancing the forensic sciences. Undoubtedly, attracting and sustaining STEM talent to address both current and future needs in the forensic sciences is a critical part of the NIJ strategy to advance forensic science, which can then be used to better ensure public safety, prevent and control crime, and ensure the fair and impartial administration of criminal justice in the United States.

\section{References}

1. Burch AM, Durose MR, Walsh KA (2016) Publically funded forensic crime laboratories: Resources and services, 2014. US Department of Justice, Office of Justice programs, Bureau of Justice statistics, Washington, DC.

2. NRC, NAS (2009) Strengthening forensic science in the United States: A path forward. Washington, DC: NPA

3. Gonzalez H, Kuenzi J (2012) Science, technology, engineering, and mathematics (STEM) education: A primer. Washington, DC: Library of congress.

4. BLS, USDL (2017) Occupational outlook handbook, 2016-17 edition, Forensic science technicians.

5. Carnevale AP, Smith N, Melton M (2011) STEM: Science technology engineering mathematics. Georgetown University Center on Education and the Workforce.

6. NAS, NAE, IM (2007) Rising above the gathering storm: Energizing and employing America for a brighter economic future.NPA: Washington DC.

7. NASEM (2015) Support for forensic science research: Improving the scientific role of the National Institute of Justice. Committee on strengthening forensic science at the National Institute of Justice. Committee on Law and Justice, Division of behavioral and social sciences and education. NPA: Washington DC. 